V. Shapovalov, A. Permyakov, A. KlochKo

\title{
MODELING OF A DUPLEX MILLER AND CONDITIONS OF FORMATION OF TREATMENT OF WHEEL PAIRS OF MAIN ELECTRIC CARDS, DUAL CARS, ELECTRO SECTIONS
}

The subject matter of the research in the article is the process of restoring the quality and accuracy of the working surface of the wheelsets of the main electric locomotives, electric sections. The purpose of the work is to develop a modeling method for a special shaped cutter with increased productivity, designed to process the profile of locomotive railway wheels taking into account the shaping processes, which is based on the theory of modeling the high-speed milling process through the shaping efficiency coefficient. The article solves the following tasks: substantiation of the importance of upgrading the most promising designs of "duplex" mills, taking into account the reduction of vibrations due to chip crushing, to increase tool wear resistance, machining accuracy, reduce tool readjustment time and, accordingly, reduce equipment downtime, increase processing productivity, determine the mathematical apparatus for calculating model parameters; development of a method for modeling and optimization of shaping processes in the processing of locomotive wheel sets. Such methods were used: fundamentals of system analysis, simulation method. The following results were obtained: the design of a "duplex" milling cutter with a predicted increase in resistance and increase in processing productivity due to modeling of forming processes with a decrease in the sliding angle by three to five times, which was not previously taken into account when designating and selecting cutting parameters, is provided. It is concluded that the model design of the cutter, taking into account "duplex" and the tribological process of modeling shaping during processing, can increase the resistance of the cutters and ensure the full operation of all cups of the cutter. The forming component of the cutting conditions was evaluated taking into account the coefficient of efficiency of the process of forming the surface layer of the machined wheel. The conclusion was made about the need to create new processes of shaping the design and modernization of tools. Various ways of modeling tool systems are considered. A method for creating a "duplex" cutter model is defined. A "duplex" mill is considered and design features of the algorithm for creating such tools are given. The functioning of the shaping parameters during the processing of locomotive wheelsets is formalized in the form of separate mathematical models and formulas, on the basis of which a method for modeling the process of increasing productivity and increasing the resistance of mills is described. Findings: Thus, a new method was created for modeling the process of shaping when machining wheel sets of locomotives with a "duplex" cutter with minimizing the cost of operating the tool and reducing the sliding angle on the arc of cutting the cutter cup with an increase in the quality and accuracy of processing, which makes it possible to significantly reduce the cost of preparing the production and increase processing efficiency.

Keywords: restoration of quality and accuracy; wheelsets; mainline electric locomotives; modeling; shaping; shaping efficiency coefficient; "duplex" mill; optimization; mill stability; processing efficiency.

\section{Introduction}

Restoring the quality and accuracy of the working surface of the wheelsets of the main electric locomotives, electric sections and diesel locomotives is a rather complicated and expensive technological operation.

During operation, wheelsets of rolling stock are subject to significant static and dynamic loads, as well as thermal effects during braking, which lead to thermo mechanical damage to the rim. Damage also causes a change in the structure of the metal, in particular, leads to a sharp increase in the hardness of individual sections of the processing surface. The average mileage of wheelsets with wheels of high hardness is up to 280 thousand $\mathrm{km}$ to the first turning, and wheels with standard hardness 110 thousand $\mathrm{km}$.

\section{Analysis of publications and problem statement}

The process of restoring locomotive wheelsets consists in machining the flanges of the wheel with the raceway and for more than 60 years has been carried out by the developed design of the cutter with cutting carbide cups mounted in cutters. The consumption of special shaped milling cutters used when turning solid wheels in comparison with the processing of standard wheels increases by 3-5 times, and the productivity of machining decreases by 2-3 times. Processing and restoration of wheel pairs of rolling stock of cars is carried out by rolling out on special wheel-turning machines of model $\mathrm{KZh}$ $1836 \mathrm{M}$ by the method of turning simultaneously with two calipers with carbide plates and does not cause such processing difficulties as when restoring wheel pairs of main locomotives of electric locomotives, diesel locomotives, electric sections.

To restore the wheelsets, special two-spindle wheel milling machines of the mod are used. KZh-20, KZh20TF1 (manufacturer - PrJSC Kramatorsk Heavy Machine Tool Plant) and prefabricated shaped mills equipped with carbide cutting elements - cups f12mm. Milling cutters for wheel milling machines are produced in Belarus (Gomel "Electromechanical Plant"), Russia (St. Petersburg, EFSI). Cutting cups are located on one side of the cutters and completely cover the entire track and wheel flange $[1,2,3]$.

In order to increase the efficiency of the wheelset recovery process, it is necessary to solve the following problems: justification of the importance of upgrading the most promising designs of "duplex" mills, taking into account vibration reduction due to chip crushing, to increase tool wear resistance, machining accuracy, reduce tool readjustment time and, accordingly, reduce equipment downtime, improve processing performance, the definition of the mathematical apparatus for calculating model parameters; development of a modeling method and optimization of shaping processes in the 
processing of locomotive wheel sets using system analysis methods and simulation methods.

\section{Justification of the importance of increasing the efficiency of shaping wheelsets}

The wheels are machined on the machine (fig. 1) without rolling out at the same time by two mills - left and right (fig. 2), which differs from each other by the location of the shaped profiles of the cutters and the direction of the bevels at their ends.

The known design of a special shaped cutter (fig. 3), designed for processing the profile of railway wheels of locomotives, contains a housing in the longitudinal inclined grooves of which flat cutters are placed at an angle $\tau=15^{\circ}$ (fig. 4) with a shaped profile along which cylindrical nests are installed; and cutting elements in the form of carbide cups f12mm are fixed with screws (fig. 5). Cutters in the cutter body are fixed with end caps using wedges and screws $[2,3,4,5]$.

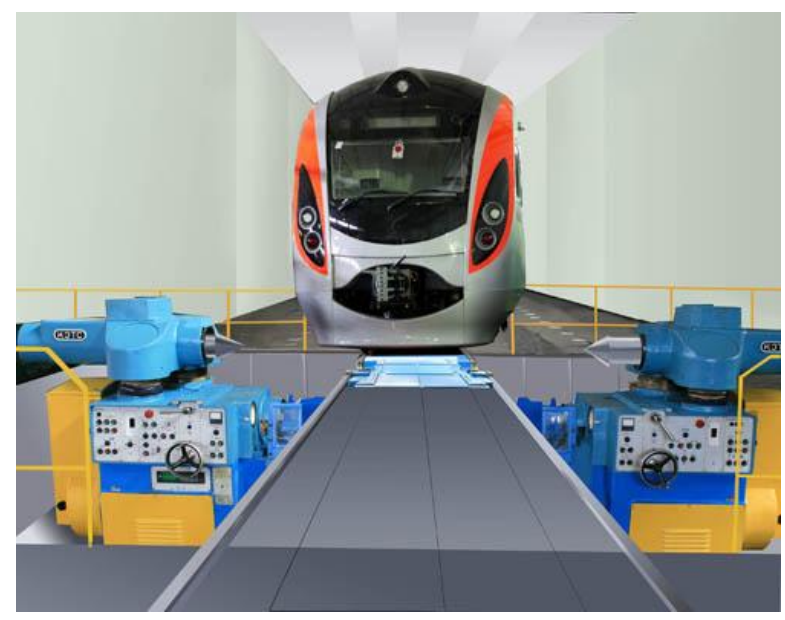

Fig. 1. Processing wheels without rolling out on a machine model KZh-20TF1
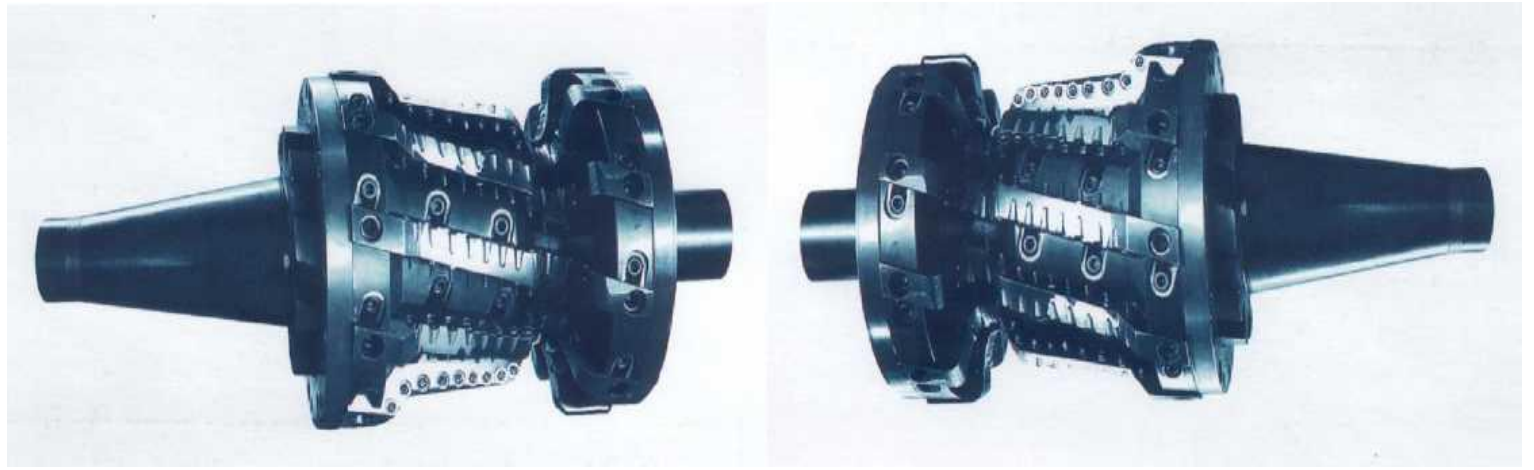

Fig. 2. Set of mills for installation on the machine mod. KZh-20TF1

At the ends of the cutters, one bevel is made at an angle to the front plane equal to the angle of inclination of the cutter in the case $\left(\tau=15^{\circ}\right)$.

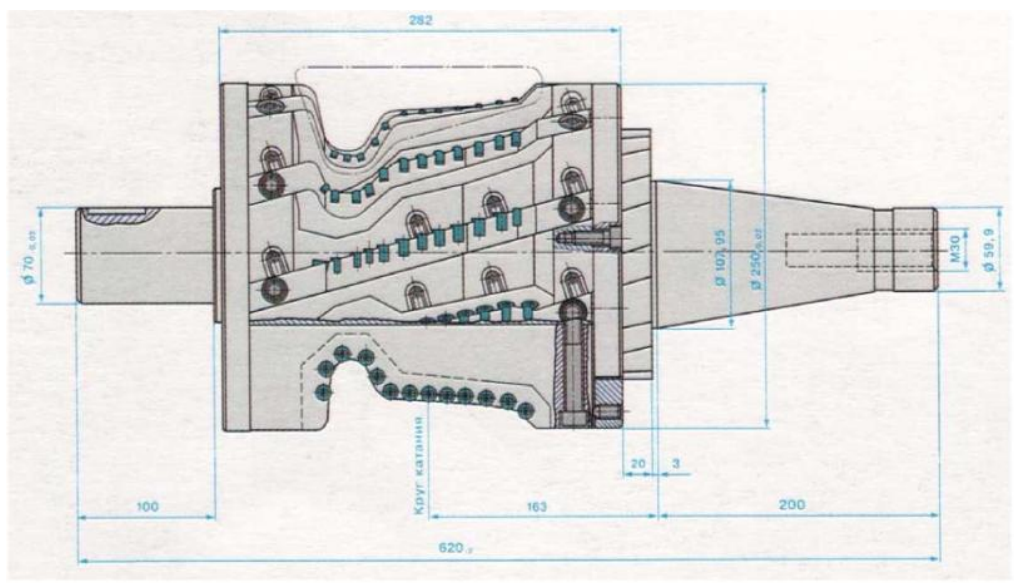

Fig. 3. Known design of a special shaped mill 


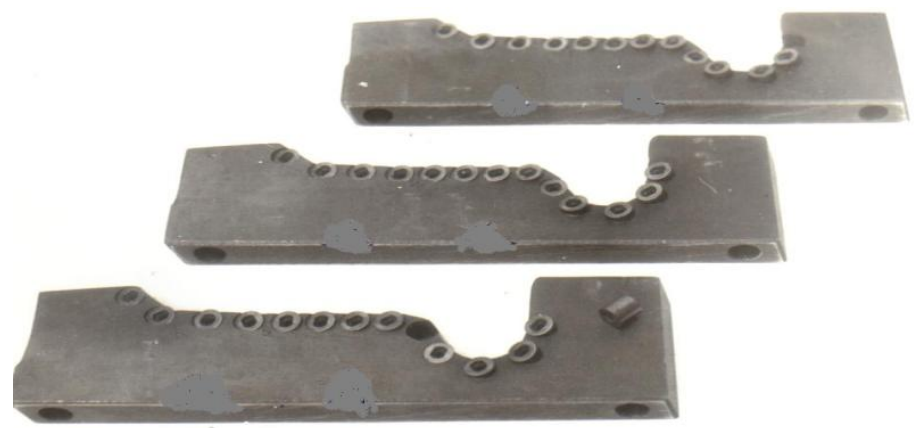

Fig. 4. Mill cutters with carbide cutting cups-rollers
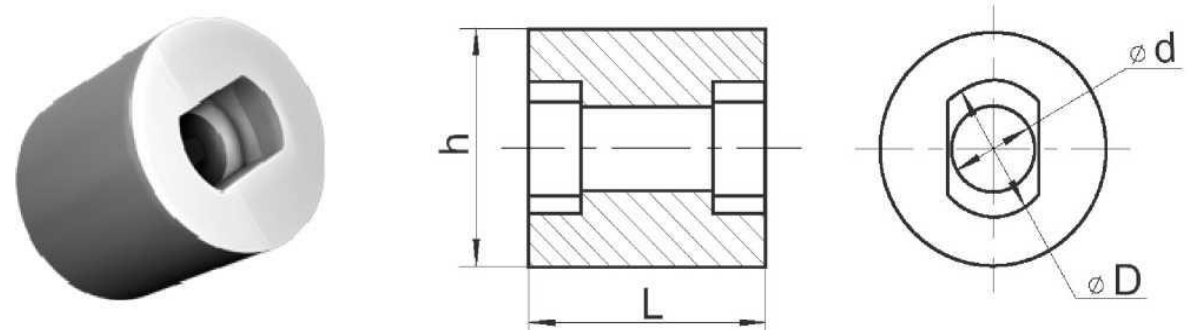

Fig. 5. Carbide cutting roller cups table 1 .

The dimensions of the cup-rollers are given in

Table 1. The dimensions of the cup-rollers

\begin{tabular}{|c|c|c|c|c|}
\hline \multirow{2}{*}{ Product designation } & \multicolumn{4}{|c|}{ Dimensions, mm } \\
\cline { 2 - 5 } & $\mathrm{L}$ & $\mathrm{D}$ & $\mathrm{d}$ & $\mathrm{h}$ \\
\hline RNUX 1212 M0 TN & 12 & 6,5 & 4,2 & 12 \\
\hline
\end{tabular}

The design of the mill provides 10 cutters, in each (fig. 4) of which 12-13 cutting cups-rollers are placed. Cups in each of the cutters are shifted in axial and radial directions in order to ensure optimal cutting conditions and obtain the necessary bandage profile. Thus, each of 120-126 cups has an individual, different position from others.

The advantage of the mill is that the long shaped edge is replaced by separate small circular edges-sectors of the cutting elements - cups $f 12 \mathrm{~mm}$, installed overlapping from cutter to cutter to ensure smooth bending around the shaped profile of the wheel bandage. This design of the mill provides a vibration-free milling process and provides chip crushing. In addition, turning carbide cutting elements - cups $\mathrm{f} 12 \mathrm{~mm}$ in the middle of their wear around the axis, and also reinstalling them on the reverse end, increases the total tool life by $8-10$ times. $[1,5,6,7]$

The round shape of the cutting edge of a relatively large curvature causes errors in the machined profile in the

range of $0.2-0.5 \mathrm{~mm}$, and the roughness of the machined surface exceeds $\mathrm{Ra}=10 \mu \mathrm{m}$. Radial run out of bandages in a circle reaches $0.3-0.5 \mathrm{~mm}$.

Hertel (Germany) proposed similar milling cutters with a diameter of the cutting element - cup Ø $65 \mathrm{~mm}$. However, a decrease in the curvature of the cutting edge and an increase in its length led, under conditions of thin but wide chips, to the appearance of tool vibrations during the cutting process. In addition, the Hertel mills are cantilevered in the machine, as except for the cone, the second supporting neck. They are not widely used in the CIS countries.

The technology of milling with shaped mills provides for the removal of the entire allowance in one revolution of the wheel. The process of operation of the tool occurs in fairly severe conditions due to unfree cutting and variable hardness of individual sections of the machined surface of the wheel bandages.

The disadvantage of the considered design of the mill is that the blades relatively quickly (after processing an average of 8 pairs of wheels) fail (fig. 6) due to the intensive abrasion of the sections of their outer surfacebased rollers located between the cutting elements. Changing the mill requires a significant amount of working time, as the manufacture of new cutters due to their complex design is characterized by a long cycle. This, in turn, leads to equipment standstill and reduced processing performance.

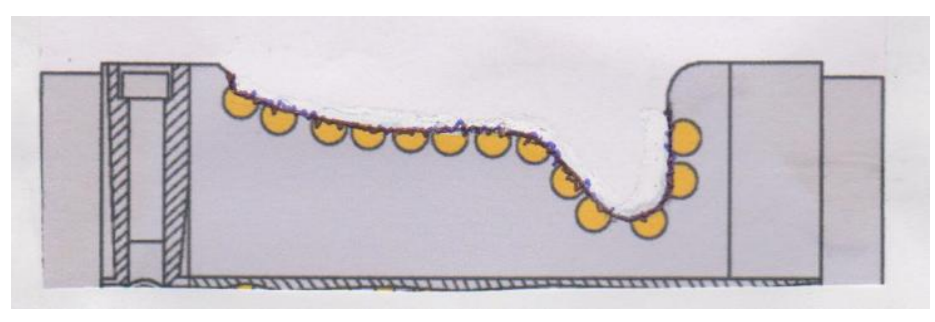

Fig. 6. Typical wear of the rollers and their bearing surfaces in rails 
A method for modeling the characteristics of "duplex" milling cutters and the processes of forming wheel sets

In the proposed new design of the mill, called "duplex" [1, 2] on shaped cutters, additional shaped profiles are provided, each of which is made on the opposite side of the corresponding cutter, and the nests for the cutting sections of the additional and main profiles are located in the same plane so that their axes form an angle are equal to the double angle of inclination of the cutters in the case. Also, an additional bevel is made at each end of the cutter, the angle of inclination of which to the main bevel is also equal to the double angle of inclination of the cutters in the case. In addition, the largest recess of each additional shaped profile is made in the opposite direction to the main direction and at the opposite end of the cutter $[1,5,7,8,9]$.

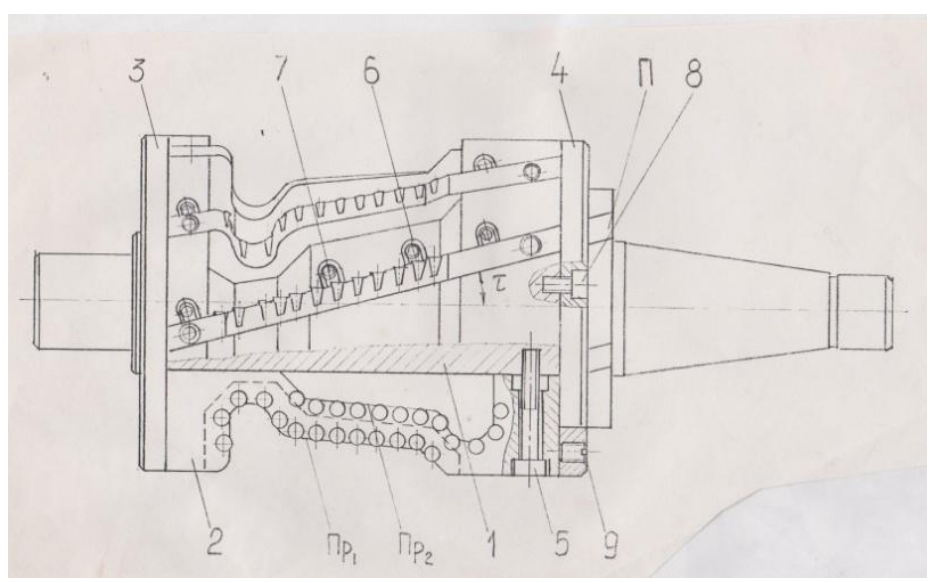

Fig. 7. New duplex design of carbide shaped mill [11]

The essence of the new design of the mill is illustrated by drawings, where fig. 7 shows a general view of the cutter; in fig. 8 - the main view of the cutter with an additional profile, in fig. 9 and fig. 10 - the cross section of the cutters at the axes of the nests and chamfers at the ends of the cutters directed under each other.

The milling cutter (fig. 7) consists of a case 1 with inclined grooves at an angle $\tau$, in which cutters 2 with a main shaped profile Pr1 and an additional profile Pr2 are placed. Cutters 2 are fixed in the case using end caps 3 and 4 , transverse screws 5 , plate wedges 6 and pressure screws 7.

In the end cover 4 , holes are provided for screws 8 , fastening it to the mill body 1 and screws 9, pressing cutters 2 to the base ring $3[1,3,10,11,12]$.

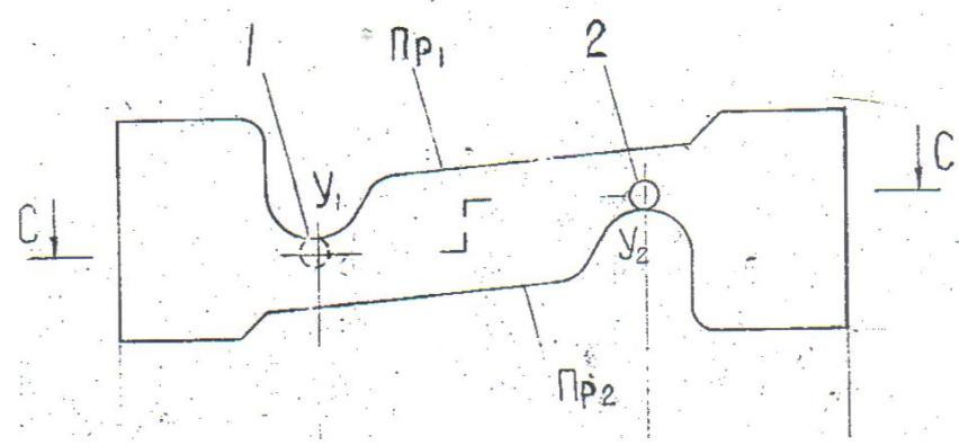

Fig. 8. The main view of the cutter with an additional profile

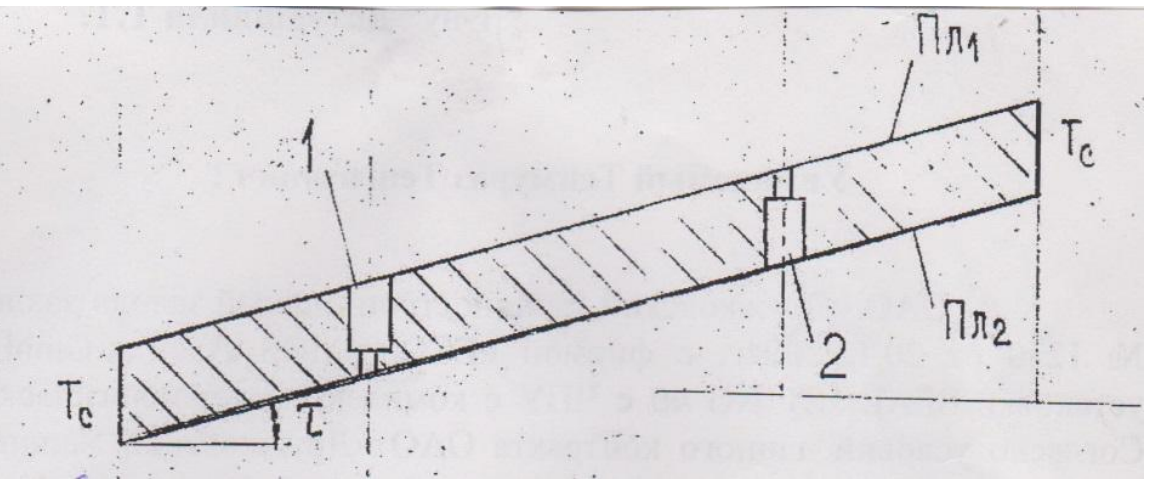

Fig. 9. The cross section of the cutter with the axis of the nests and chamfers at the ends of the cutter 
Cylindrical nests 1 and 2 (fig. 8, fig. 9 and fig. 10) for cutting elements - cups $\mathrm{f} 12 \mathrm{~mm}$ are made along the main shaped profile $\operatorname{Pr} 1$ and additional $\operatorname{Pr} 2$, and the largest recess of the additional profile $\mathrm{U} 2$ is made in relation to the recess of the main profile in the opposite direction and at the opposite end of the cutter.

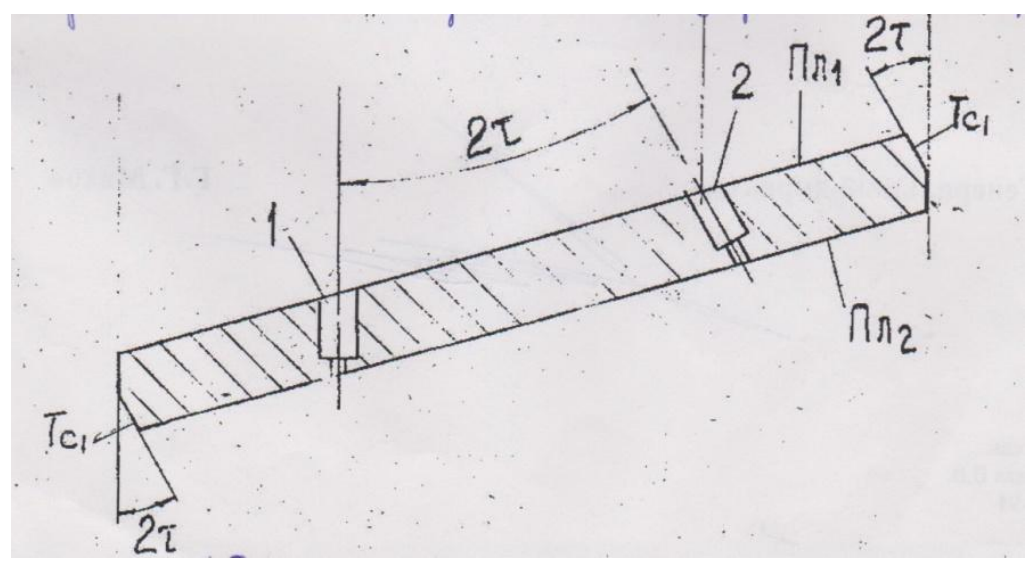

Fig. 10. The cross section of the cutter with the axis of the nests and chamfers at the ends of the cutter, directed at an angle of $2 \tau$ to each other

To ensure the use of cutters with an additional profile $\operatorname{Pr} 2$ in the case of the same cutter, for example, the maiden or right, the sockets 2 of the additional profile (fig. 9 and fig. 10) are made on the plane Pl1, i.e. in the same place as the cutters in the case $-2 \tau$. In addition, at each end of the cutter, an additional bevel Tc1 is made, which is also inclined to the nests 1 of the main profile $\operatorname{Pr} 1$, but their axes are located at an angle to the axes of the nests 1, equal to the double angle of inclination of the cutters with respect to the main bevel $\mathrm{Tc}$ at an angle of $2 \tau$. Thus, after failure of the cutters along the Pr1 profile, they can be reinstalled in the housing of the same cutter to work along the Pr2 profile based on the Tc1 bevels.

The execution of nests for cups $112 \mathrm{~mm}$ in an additional profile on the same plane with the nests of the main profile, but with an inclination of their axes at an angle of $2 \tau$, provides after reinstalling the cutters in the housing the location of the front cutting surfaces of the cups f12mm of both profiles.

Performing additional bevels on the ends of the cutters at an angle of $2 \tau$ to the main bevels allows, after reinstalling the cutters in the case to work with an additional profile, to ensure the necessary fit of the ends of the cutters to the end caps, namely, along the plane, and not along the sharp edge.

The exclusion from the specified combination of at least one of the listed structural elements will not allow achieving the planned result.

The proposed design of the mill (fig. 11) can significantly reduce the tool changeover time and, accordingly, reduce equipment downtime, increase processing productivity.

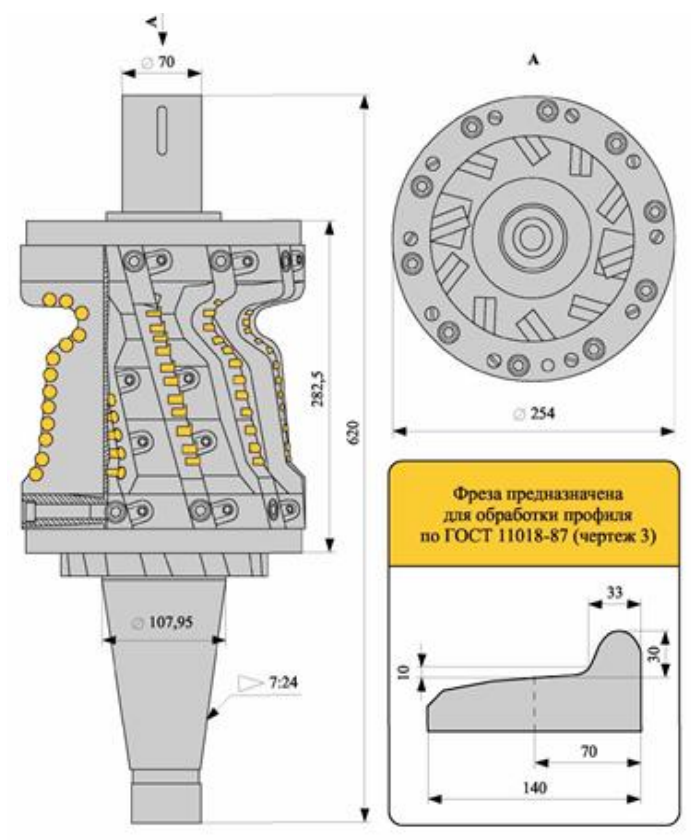

Fig. 11. Duplex design of carbide shaped milling cutter for machining a wheel profile according to GOST 11018-87 (drawing 3)

The selection and designation of the most effective cutting modes is based on the theory of modeling the process of high-speed milling $[8,12,13,14,15,16]$ through the efficiency of shaping $K \rho$. (1) 


$$
K_{\rho}=\frac{\sin \Psi_{\max }-\sin \Psi_{S K}}{\sin \Psi_{\max }} \cdot 100 \% .
$$

Substituting the technological processing parameters in (1), we obtain an expression of the coefficient of formation efficiency, convenient for theoretical and experimental studies:

$$
K_{\rho}=\left(\frac{\arcsin \left(K_{C} \cdot \frac{\rho \cdot 10^{3} \cdot V \cdot Z}{S_{\min i} \cdot \pi \cdot d_{f r} \cdot \sin \varphi}\right)}{\arcsin \frac{2 \cdot \sqrt{t \cdot\left(d_{f r}-t\right)}}{d_{f r}}}\right) \cdot 100 \% .
$$

where $K_{C}=0,5$ when machining with carbide cutting cup RNUX 1212 M0 TN without coolant.

During milling, the variable thickness of the cut-off layer ai is defined as the distance between two consecutive trajectories of the cup point $f 12 \mathrm{~mm}$, measured in the direction of the mill radius and determining the instantaneous position of the contact angle. The thickness of the cut is simplified by the formula (3):

$$
a_{i}=S_{Z \min } \cdot \sin \Psi_{s l} \cdot \sin \phi,
$$

where $S_{Z \min }$ - minimum feed to the cutting edge of the cup f12 $\mathrm{mm}$ (tooth of a duplex carbide shaped mill) at which the process of milling the wheel, flange begins.

Thus, the start of milling without coolant begins when $a_{i}>0.5 \rho$. Then, given the value $S_{Z \min }$, the sliding angle is determined $\psi_{s l}$.

Sliding occurs at a certain sliding angle $\psi_{s l}$ until plastic deformations go directly from cutting from micro cutting, i.e. when the thickness of the cut does not reach a certain depth, relative to the introduction of a cup $112 \mathrm{~mm}$ having a radius of rounding of the cutting edge $\rho$.

Thus, improving the quality of the surface layer of locomotive wheelsets, reducing roughness, significantly increasing productivity and regulated durability of a duplex carbide shaped mill is ensured by establishing a fixed feed rate at which the ratio of the initial cut thickness to the rounding radius of the cutting edge of the mill corresponds to the smallest sliding angle.

Sample. When milling wheelsets with a duplex carbide shaped mill with a diameter of $D=250 \mathrm{~mm}$, the number of cutters $z=10$, a cutting speed of $3 \mathrm{~m} / \mathrm{s}$, and a minute feed $S_{\min }=230 \mathrm{~mm} / \mathrm{min}$. feed per tooth, $S_{z}=0.1$ $\mathrm{mm} /$ tooth, radius of the cutting blade $\rho=0.25 \mathrm{~mm}$, angle of inclination of the cutter in the cutter body $\varphi=20^{\circ}$ :

$$
\Psi_{s l \text { min }}=\arcsin 0,453216 \approx 27^{\circ} ;
$$

$a=0,1 \cdot \sin 27^{\circ} \cdot \sin 20^{\circ}=0.016 \mathrm{~mm}$.

When gear hobbing with different values of $\rho$, the minimum slip angles are obtained:

$$
\begin{aligned}
& \rho=0.25 \mathrm{~mm}, S_{Z \min }=0,1 \mathrm{~mm} / \text { tooth }, \Psi_{s l \min }=27^{\circ} ; \\
& \rho=0.25 \mathrm{~mm}, S_{Z \text { min }}=0,5 \mathrm{~mm} / \text { tooth }, \Psi_{s l \min }=5^{\circ} 12^{\prime} ; \\
& \rho=0.1 \mathrm{~mm}, S_{Z \text { min }}=0,5 \mathrm{~mm} / \text { tooth, } \Psi_{s l \min }=5^{\circ} 26^{\prime} .
\end{aligned}
$$

Thus, an increase in the machining performance of the wheel flanges with the smallest sliding angle is achieved in the above example for $\rho=0.25 \mathrm{~mm}$, $S_{Z_{\text {min }}}=0,5 \mathrm{~mm} /$ tooth, $\Psi_{s l \text { min }}=5^{\circ} 12^{\prime}$.

The use of the developed technological regulations for the selection and assignment of processing parameters during high-speed milling, taking into account the required parameters of the surface layer of locomotive wheels, establishes optimal milling conditions under which full participation of all mill teeth is ensured.

Determination of minimum sliding angles when machining wheels by milling, based on the physicochemical processes of friction mechanics, can significantly increase the efficiency of the process of forming wheels and the operational properties of their surfaces.

Theoretical and experimental studies allow us to determine the optimal sliding angles $\psi_{s l}$, at which the milling process is stable, the necessary conditions for tool life and the quality of the machined surface with respect to the largest contact angle of the cutter tooth $\psi_{\max }$ with the machined wheel.

The presence of additional shaped profiles on the mill cutters allows for quick readjustment of the tool without removing it from the machine by reinstalling the cutters in the case to use additional shaped profiles and this significantly reduces equipment downtime and increases processing productivity.

\section{Conclusions}

1. The possibility of modeling the design of the mill is shown, which ensures the milling process without vibrations due to chip crushing.

2. By choosing this method of processing with a "duplex" mill, it is possible to significantly increase the tool wear resistance, reduce vibration loads, and improve processing accuracy.

3. The arrangement of insert cutters of the provided additional shaped profiles is shown, each of which is made on the opposite side of the corresponding cutter.

4. The proposed design of the "duplex" mill can significantly reduce the tool changeover time and, accordingly, reduce equipment downtime, increase processing productivity.

5. The selection and designation of the most effective cutting modes is based on the theory of modeling the process of high-speed milling through the coefficient of efficiency of forming $K \rho$.

6. Determination of minimum sliding angles when machining wheels by milling, based on the physicochemical processes of friction mechanics, can significantly increase the efficiency of the process of forming wheels and the operational properties of their surfaces.

7. The conducted theoretical and experimental studies allow us to regulate the optimal sliding angles $\psi_{s l}$, at which the stability of the milling process is ensured. 


\section{References}

1. Shapovalov, V. F., Lishaev, G. P., Anastasov, S. A. et al. (1995), Pat. 25406A B23 C 5/00, Ukraine, Combined shaped milling cutter, 12/23/93; publ. 05/29/95, Bull. No. 21, 5 p.

2. Belovol, A. V., Klochko, A. A., Naboka, E. V., Skorkin, A. O., Silk. A. N. (2016), Simulation modeling in the problems of engineering production in 2 volumes, Vol. 1: textbook. allowance, Kharkiv : NTU "KhPI", 400 p. ISBN 978-966-593-749-4

3. Fadeev, V. A., Silkova, O. N., Hitsan, V. D., Klochko, A. A. (2015), "Integration technological preparation of an industrial enterprise PLM - decision", News of NTU "KhPI". Seriya: Technologies in machine-assisted suction, No. 4 (1113), P. 4-10.

4. Shelkovoy, A., Klochko, A., Naboka, E. (2015), Simulation in the problems of mechanical assembly production, Saarbrücken, Germany : LAP LAMBERT Academic Publishing, 528 p.

5. Timofeev, Yu. V., Klochko, A. A., Shapovalov, V. F. (2010), "Technology of gear hobbing of hardened large-modular wheels with special worm milling cutters with minimizing parameters of the main cutting edges", Scientific notes: mizhvuz. zb., Lutsk, Vol. 29, P. 209-216.

6. Stepanov, M. S., Klochko, A. A., Kravtsov, A. N. (2015), "Multicriteria regulation of the parameters of the surface layer of parts", Physical and computer technology. Proceedings of the 21st International Scientific and Practical Conference. December 24-25, 2015, Kharkov, D. : Lira, P. 68-76.

7. Timofeev, Yu. V., Klochko, A. A., Shapovalov, V. F. (2011), "New technology for high-speed machining of hardened largemodular gears with special disk cutters", News of SevNTU. Series "Mashinopriladobuduvannya that transport", Sevastopol, Vol. 118, P. 139-144.

8. Mironenko, E. V., Shapovalov, V. F., Klochko, A. A., Broadsword, S. Yu., Ostapovich, E. V. (2015), "Design and technological methods for increasing productivity and quality of gear processing of large gears", News of NTU "KhPI". Seriya: Technologies in machine-assisted suction, No. 4 (1113), P. 28-32.

9. Ravskaya, N. S., Ohrimenko, O. A., Melnichuk, P. P., Nicola, T. P. (2013), The basics of shaping on top with mechanical testing, Navalny postnik with the stamp of the Ministry of Education and Science of Ukraine (No. 1 / 11-5203, March 12, 2013), Kyiv : SKDDruk.

10. Joseph Stokes (2008), The Theory and Application of the HVOF Thermal Spray Process, Dublin City University. 206 p.

11. Shapovalov, V. F., Permyakov, A. A., Klochko, A. A., Lyshenko, A. N. (2017), "High-speed hobbing of hardened gears", Vazhke machine blowing. Problems and prospects for development: materials of the fifteenth Mizhnar. science. conf., Kramatorsk : DDMA, P. 96.

12. Sudhansu Ranjan Das, Amaresh Kumar, Debabrata Dhupal (2013), "Effect of Machining Parameters on Surface Roughness in Machining of Hardened AISI 4340 Steel Using Coated Carbide Inserts", International Journal of Innovation and Applied Studies, Vol. 2, No. 4, P. 445-453.

13. Kane, M. M., Suslov, A. G., Gorlenko, O. A. et al. (2010), Quality management of engineering products, Moscow : Mechanical Engineering, $416 \mathrm{p}$.

14. Johny Shaida Shaik, K.Rajasekhara Babu (2012), "Prediction of surface roughness in hard turning by using fuzzy logic", International Journal of Emerging Trends in Engineering and Development, Issue 2, Vol. 5, P. 38-49.

15. Shelkova, A. N., Permyakov, A. A., Klochko, A. A., Antsyferova, O. A., Shapovalov, V. F. (2017), "Technological possibilities of gear processing of high-precision large-sized gears", Complex safety management of technological processes of systems (KZYATPS - 2017): materials of additional technologies of the VII international scientific-practical conference, Chernigiv : ChNTU, Vol. 1, P. $163-164$.

16. Klochko, A., Shelkovoy, A., Shapovalov, V., Belovol, A., Antsyferova, O. (2017), "Technology of repair and restoration of largemodular golden gear wheels by high-speed wood processing", Innovative Technologies and Scientific Solutions for Industries, No. 2 (2), P. 38-47. DOI: https://doi.org/10.30837/2522-9818.2017.2.038.

Received 19.08.2019

\section{Відомості про авторів / Сведения об авторах / About the Authors}

Шаповалов Віктор Федорович - кандидат технічних наук, ВАТ "Науково-дослідний проектно-технологічний інститут машинобудування", старший науковий співробітник, Краматорськ, Україна; e-mail: shapovalov42@ukr.net; ORCID: http://orcid.org/0000-0002-2688-8242.

Шаповалов Виктор Федорович - кандидат технических наук, ОАО "Научно-исследовательский проектнотехнологический институт машиностроения", старший научный сотрудник, Краматорск, Украина.

Shapovalov Victor - PhD (Engineering Sciences), OAO "Research and Design Institute of Mechanical Engineering", Senior Researcher, Kramatorsk, Ukraine.

Пермяков Олександр Анатольович - доктор технічних наук, професор, Національний технічний університет "Харківський політехнічний інститут", завідувач кафедри технологія машинобудування та металорізальні верстати, Харків, Україна; e-mail: perm_a@i.ua; ORCID: http://orcid.org/0000-0002-9589-0194.

Пермяков Александр Анатольевич - доктор технических наук, профессор, Национальный технический университет "Харьковский политехнический институт", заведующий кафедрой технология машиностроения и металлорежущих станков, Харьков, Украина.

Permyakov Alexandr - Doctor of Sciences (Engineering), Professor, National Technical University "Kharkiv Polytechnic Institute", Head of the Department of Technology of Mechanical Engineering and Metal-Cutting Machines", Kharkiv, Ukraine.

Клочко Олександр Олександрович - доктор технічних наук, професор, Національний технічний університет "Харківський політехнічний інститут", професор кафедри технології машинобудування та металорізальних верстатів, Харків, Україна; e-mail: ukrstanko21@ukr.net; ORCID: http://orcid.org/0000-0003-2841-9455. 
Клочко Александр Александрович - доктор технических наук, профессор, Национальный технический университет "Харьковский политехнический институт", профессор кафедры технологии машиностроения и металлорежущих станков, Харьков, Украина.

Klochko Alexander - Doctor of Sciences (Engineering), Professor, National Technical University "Kharkiv Polytechnic Institute", Professor of the Department of Technology of Machine Building and Metal Cutting Machine, Kharkiv, Ukraine.

\section{МОДЕЛЮВАННЯ ДУПЛЕКСНОЇ ФРЕЗИ І УМОВ ФОРМОУТВОРЕННЯ ОБРОБКИ КОЛІСНИХ ПАР МАГІСТРАЛЬНИХ ЕЛЕКТРОВОЗІВ, ТЕПЛОВОЗІВ, ЕЛЕКТРОСЕКЦІЙ}

Предметом дослідження в статті $\epsilon$ процес відновлення якості і точності робочої поверхні колісних пар магістральних електровозів, електросекцій. Мета роботи - розробка методу моделювання спеціальної фасонної фрези 3 підвищеної продуктивності, призначеної для обробки профілю залізничних коліс локомотивів з урахуванням процесів формоутворення, яка базується на теорії моделювання процесу швидкісного фрезерування через коефіцієнт ефективності формоутворення. У статті вирішуються наступні завдання: обгрунтування важливості модернізації найбільш перспективних конструкцій "дуплексних" фрез з урахуванням зниження вібрацій за рахунок дроблення стружки, підвищити зносостійкість інструменту, точність обробки, знизити час переналагодження інструмента i, відповідно, знизилася не простої обладнання, підвищити продуктивність обробки, визначення математичного апарату для обчислення параметрів моделі; розробка методу моделювання та оптимізації процесів формоутворення при обробці колісних пар локомотивів. Використовуються такі методи: основи системного аналізу, метод імітаційного моделювання. Отримані наступні результати: надано конструкція "дуплексної" фрези про прогнозованим підвищенням стійкості і підвищенням продуктивності обробки за рахунок моделювання процесів формоутворення при зменшенні кута ковзання в три-п'ять разів, що раніше не враховувалася при призначенні і виборі параметрів різання. Зроблено висновок, що моделювання конструкції фрези 3 урахуванням "дуплексності" і трибологічних процесів моделювання формоутворення при обробці дозволяють підвищити стійкість фрез і забезпечити повну роботу всіх чашок фрези. Була оцінена формотворна складова режимів різання з урахуванням коефіцієнта ефективності процесу формування поверхневого шару оброблюваного колеса. Зроблено висновок про потребу створення нових процесів формоутворення проектування і модернізації інструментів. Розглянуто різні способи моделювання інструментальних систем; визначений спосіб створення моделі "дуплексної" фрези. Розглянуто "дуплексна" фреза i приведені конструктивні особливості алгоритму створення таких інструментів. Функціонування параметрів формоутворення при обробці колісних пар локомотивів формалізовано у вигляді окремих математичних моделей і формул, на основі яких описаний метод моделювання процесу підвищення продуктивності і підвищення стійкості фрез. Висновки: таким чином, створений новий метод моделювання процесу формоутворення при обробці колісних пар локомотивів "дуплексної" фрезою 3 мінімізацією витрат на експлуатацію інструменту і зниження кута ковзання на дузі різання чашки фрези 3 підвищенням якості і точності обробки, що дає можливість значно знизити витрати на підготовку виробництва і підвищити ефективність обробки.

Ключові слова: відновлення якості і точності; колісні пари; магістральні електровози; моделювання; формоутворення; коефіцієнт ефективності формоутворення; "дуплексна" фреза; оптимізація; стійкість фрези; ефективність обробки.

\section{МОДЕЛИРОВАНИЕ ДУПЛЕКСНОЙ ФРЕЗЫ И УСЛОВИЙ ФОРМООБРАЗОВАНИЯ ОБРАБОТКИ КОЛЕСНЫХ ПАР МАГИСТРАЛЬНЫХ ЭЛЕКТРОВОЗОВ, ТЕПЛОВОЗОВ И ЭЛЕКТРОСЕКЦИЙ}

Предметом исследования в статье является процесс восстановления качества и точности рабочей поверхности колесных пар магистральных электровозов, электросекций. Цель работы - разработка метода моделирования специальной фасонной фрезы с повышенной производительности, предназначенной для обработки профиля железнодорожных колес локомотивов с учетом процессов формообразования, которая базируется на теории моделирования процесса скоростного фрезерования через коэффициент эффективности формообразования. В статье решаются следующие задачи: обоснование важности модернизации наиболее перспективных конструкций "дуплексных" фрез с учетом снижения вибраций за счет дробления стружки, повысить износостойкость инструмента, точность обработки, снизить время переналадки инструмента и, соответственно, снизать простои оборудования, повысить производительность обработки, определение математического аппарата для вычисления параметров модели; разработка метода моделирования и оптимизации процессов формообразования при обработке колесных пар локомотивов. Используются такие методы: основы системного анализа, метод имитационного моделирования. Получены следующие результаты: Предоставлена конструкция "дуплексной" фрезы о прогнозированным повышением стойкости и повышением производительности обработки за счет моделирования процессов формообразования при уменьшении угла скольжения в три-пять раз, что ранее не учитывалось при назначении и выборе параметров резания. Сделан вывод, что моделирование конструкции фрезы с учетом "дуплексности" и трибологического процесса моделирования формообразования при обработке позволяют повысить стойкость фрез и обеспечить полную работу всех чашек фрезы. Была оценена формообразующая составляющая режимов резания с учетом коэффициента эффективности процесса формирования поверхностного слоя обрабатываемого колеса. Сделан вывод о потребности создания новых процессов формообразования проектирования и модернизации инструментов. Рассмотрены различные способы моделирования инструментальных систем; определен способ создания модели "дуплексной" фрезы. Рассмотрена "дуплексная" фреза и приведены конструктивные особенности алгоритма создания таких инструментов. Функционирование параметров формообразования при обработке колесных пар локомотивов формализовано в виде отдельных математических моделей и формул, на основе которых описан метод моделирования процесса повышение производительности и повышения стойкости фрез. Выводы: Таким образом, создан новый метод моделирования процесса формообразования при обработке колесных пар локомотивов "дуплексной" фрезой с минимизацией затрат на эксплуатацию 
инструмента и снижения угла скольжения на дуге резания чашки фрезы с повышением качества и точности обработки, что дает возможность значительно снизить затраты на подготовку производства и повысить эффективность обработки.

Ключевые слова: восстановления качества и точности; колесные пары; магистральные электровозы; моделирование; формообразование; коэффициент эффективности формообразования; "дуплексная" фреза; оптимизация; стойкость фрезы; эффективность обработки.

\section{Бібліографічні описи / Bibliographic descriptions}

Шаповалов В. Ф, Пермяков О. А., Клочко О. О. Моделювання дуплексної фрези і умов формоутворення обробки колісних пар магістральних електровозів, тепловозів, електросекцій. Сучасний стан наукових досліджень та технологій в промисловості. 2019. № 3 (9). C. 118-126. DOI: https://doi.org/10.30837/2522-9818.2019.9.118.

Shapovalov, V., Permyakov, A., Klochko, A. (2019), "Modeling of a duplex miller and conditions of formation of treatment of wheel pairs of main electric cards, dual cars, electro sections", Innovative Technologies and Scientific Solutions for Industries, No. 3 (9), P. 118-126. DOI: https://doi.org/10.30837/2522-9818.2019.9.118. 